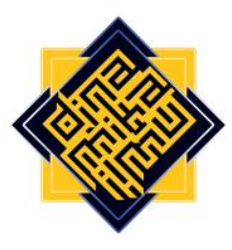

\title{
A Critical Study of Al-Farabi Philosophy Implementation at Education non-Islamic Higher Education in Indonesia
}

\author{
Ahmad Asmuni \\ Faculty of Ushuludin Adab and Da'wah \\ State Islamic Institute (IAIN) Syech Nurjati Cirebon, Indonesia \\ e-mail: ahmadasmuni1158@gmail.com
}

\section{Abstract}

The purpose of this study is to conduct a critical study of Alfarabi's philosophy in the implementation of education at Islamic universities in Indonesia. The research method used is a literature study using a philosophical approach. The main data sources are in the form of Alfarabi's work entitled Risalah fi al-'Aql and previous research works that reveal the philosophical thoughts of Islamic education put forward by Alfarabi. The findings reveal that the Alfarabi philosophy is implemented in the practice of education at Islamic universities in Indonesia through the scope, objectives, and benefits of education. First, the scope of education taught is about the concept of reason (intelligence). Second, the purpose of education is to prepare students through the transfer of knowledge and practical skills to obtain the perfection of life as human beings. Third, the benefits of the concept of value through morality development, teaching methods, and learning evaluation. The research concludes that Afarabi's philosophy in implementing education in higher education is very important for students and lecturers to improve self-competence. The expected implication is that Islamic Universities not only focus on information and communication technology but also implement the values of Islamic philosophy of life in accordance with the guidelines of the Qur'an and al-Hadith.

Keywords: Al-Farabi, education, Islamic college, philosophy 


\section{Ahmad Asmuni}

\section{A. Introduction}

Today's economic dimension has dominated society's demands for education. Information and communication technology is the main focus as a source of modern education (Stosic et al., 2020). The current consideration of society rests on a more contemporary partial scope. According to Biesta (2021), education today should be worldcentered rather than centered on the educational curriculum. Therefore, students must be equipped with knowledge and skills to be able to act logically and effectively. This new trend in higher education has prompted serious efforts from stakeholders in realizing educational goals and improving people's welfare (Türk et al., 2018). Not only empirical studies, but theoretical problems will also fundamentally affect education in higher education.

Islamic higher education in Indonesia is a higher education institution that is globally recognized by the world. Not without reason, the World University Ranking (UniRank) has released the Top Islamic University and has made three Islamic universities in Indonesia enter the top 15 of the UniRank version of the Top 15 Islamic University 2021. One of them was ranked third, namely the University of Muhammadiyah Surakarta. This ranking is based on several accreditation criteria, including; availability of postgraduate degrees (master or doctoral), and lectures in traditional educational formats (UniRank, 2021).

Islamic Universities are growing rapidly since modern Islamic civilization (Abbas, 2021). The treasures of Islamic knowledge that contribute to the economy and social life make Islamic universities attract a lot of interest from students around the world, especially in Southeast Asia with an extraordinary Islamic education structure (Setiawan, 2020). Regardless of its existence, reform of the education system is urgently needed to support the achievement of today's educational goals. Therefore, various scientific studies play an important role in education that will be implemented in Islamic universities (Sonita et al., 2021). One of them is the implementation of education from a philosophical point of view where the very rapid development of science and technology has strengthened the understanding of pragmatism-utilitarianism so that everything tends to seem practical for life (Putra \& Aslan, 2020; Maslaha et al., 2018). As a result, the understanding and orientation of education in Islamic Higher Education has been pragmatized. Such a phenomenon makes the demands of society on Islamic Universities shift from demands that are idealistic in nature to become more pragmatic-pragmatic.

The reality in universities today is that the development of the philosophy of science is still lacking (Jamal, 2017; Rahim, 2018; Karo, 2020). Students become unable to produce their own ideas, ideas, and opinions except those that have been written in the subject matter at higher education institutions. The study found that the low image of Islamic universities and efforts to improve the quality of performance so that generally students and outputs of Islamic universities have not been able to optimize their thinking abilities correctly and correctly because they are more likely to memorize and imitate the legacy of thought without understanding its meaning. In fact, many students only attend formal lectures just to pursue the semester credit system (SMS) target without the motivation to build self-competence (Ramdhan \& Siregar, 2019). 
The importance of philosophy in scientific development in higher education cannot be denied. According to Ye (2019), philosophy can build a scientific view of the values of life and the spirit of nationalism for students. Its philosophy and practice can revolutionize contemporary education and science (Guha, 2018). This is because philosophy contributes to human reasoning to build knowledge (Simas, 2020). Likewise with the philosophy put forward by Islamic religious figures who play a role in logical human thinking patterns to solve problems in life (Huzain, 2018). One of the famous philosophers is Al-Farabi. Alfarabi was the first Muslim philosopher to classify knowledge and learning in education (Abdul Majid, 2017). The study states that philosophy is the root of all knowledge because philosophy is the basis for the development of existing knowledge in higher education (Husaini, 2020). Based on the background of the problem that the researcher put forward, most of the previous research focused on investigating the study of the use of information technology in higher education, learning trends, implementation of higher education curriculum, and dynamics of learning practices. There are still very few previous studies examining the philosophy of Islamic education figures which have implications for education in Islamic universities. Therefore, this study focuses on critically examining the philosophy of al-farabi in the implementation of education at Islamic universities in Indonesia.

\section{B. Literature Review}

\section{Philosophy of Education}

Philosophy of education is also called the science of philosophy which provides a critical analysis of systematic assumptions about the nature of implementation and education in a critical, structured manner, and examines its benefits. The materials studied are the objectives, background, procedures, results, and the nature of particular education. Educational philosophy seeks to study educational policies, criticizes the relationship between educators and students in learning, examines curriculum theory and aspects of education that influence it (Husaini, 2020). The study states that the philosophy of education in Islam is useful as adab in the educational process to produce reliable and understanding human beings (Gholib, 2009). The objects of study are; "(1) ideal human nature as the main reference for knowledge; (2) education and values adopted as the basis for thinking in social life; (3) educational goals as the direction of model development; (4) the relationship between education and students; (5) understanding and implementation of the education curriculum; (6) adjustment of learning methods and strategies; (7) the relationship between educational institutions and the social environment; (8) values and knowledge; (9) solutions to educational problems (Kristiawan, 2016)." Thus the main point of the philosophy of education is what education really is, what is the purpose of education, and the methods used to achieve it. The philosophy of education has four goals, namely; (1) inspirational, namely the purpose of expressing educational ideals; (2) analytic, namely finding and examining the meaning and practice of education; (3) prescriptive, namely providing clear guidelines for educational practice; and (4) investigation, namely the adoption of educational policies and practices. The interactive relationship between 


\section{Ahmad Asmuni}

philosophy and education is able to produce self-innate potential that is in accordance with the values in society (Djamaluddin, 2014).

\section{College Education}

College is an optional final stage of informal education in the form of universities, academics, high schools, or educational institutions. Higher education is also a place for seeding thinkers, intellectuals, and professionals with a religious line of scientific thought (Beach, 2012). In practice, educational success in higher education is measured by retention and graduation rates. Therefore, it is very important to understand education to assist practitioners in programming design and institutional investment (Woods et al., 2018). The main function of higher education is to develop and disseminate knowledge through education and teaching activities to form competence academically or known as philosophical-logical terms. Higher education emphasizes aspects of education, research, and community service (Irianto, 2012; Bhakti, 2017). Education is a process of changing attitudes and behavior levels of individuals or groups in an effort to mature humans through teaching and training efforts. Higher education as a research institution is an activity carried out based on scientific principles and methods in a branch of science. Community service is an activity of the academic community that utilizes science and technology to advance society. The factors that determine the quality of education in higher education are the learning process, educational curriculum, student affairs and academic atmosphere, infrastructure, governance and contributions (Singgih \& Industri, 2008).

\section{Research Methodology}

The research method used is a literature study using a philosophical approach. The literature study method is a series of data collection techniques by conducting a review study of the literature, notes, and reports that have to do with the research problem (Nazir, 1988). With this research method, researchers have a broader depth in studying Alfarabi's thoughts in Islamic education. The philosophical approach to dissecting Islamic studies is capable of in-depth, integral, and comprehensive coverage covering the ins and outs of knowledge of the nature of Islamic education, its origins, methods, to the elements contained in it is giving birth to understanding and thinking about Islam (Halik, 2013). The main data source is secondary data derived from Alfarabi's book entitled Risalah fi al-'Aql and previous research that reveals the philosophical thoughts of Islamic education put forward by Alfarabi. This study focuses on two main topics, namely Alfarabi's thoughts on Islamic education and its implementation in Islamic universities. The research location is at Islamic universities in Indonesia.

\section{Findings and Discussion}

This research has revealed a critical study of Al-farabi's philosophy in the implementation of education at Islamic universities in Indonesia. The findings reveal that Al-farabi's philosophy which is implemented in education at tertiary institutions 
contributes greatly to lecturers and students. Lecturers and students can build their philosophical abilities in processing thoughts to criticize various thoughts and produce scientific and cultural works. The literature mentions that there are at least three scientific dimensions that can be built. First, the critical dimension aims to build self-autonomy and the ability to assess life and question various scientific, ideological, juridical, and religious possibilities in the context of developing self-existence. Second, the creative dimension aims to cultivate intelligence, theoretical imagination, and solve various life problems. Third, the contemplative dimension aims to sharpen data and the ability to direct oneself so that one becomes a more solid person and has the principle of living with dignity (Ikhwan, 2016).

Three important bases that the researcher examines, namely the scope, objectives, and benefits of Al-farabi's educational philosophy as contained in his work entitled Risalah fi al-'Aql where this book describes the importance of the concept of reason (intelligence) in the world of Islamic education. In terms of its scope, Alfarabi's philosophy tries to get an overall picture of the mind which is reflected in human attitudes and actions. In addition, he has also classified knowledge and learning as well as the importance of evaluating learning in education. In his work, Al-farabi explains that "reason is classified into four dimensions, namely potential reason ('aql bi al-quwwa), actual reason ('aql bi al-fi'l), accomplished reason ('aql mustafad), and active reason (aql al-fa'al) (Kindi, 1950)." Learning must begin by teaching students about language and its structure because language is the most important instrument in education where students can express themselves. Learning evaluation needs to be carried out in every teaching to determine the level of ability and understanding of students after passing a certain level of education (Widiawati, 2019; Parens, 2012)." If viewed from the dimensions of the scope of education in Alfarabi's perspective, Islamic universities must prioritize students' questions and demand the readiness of lecturers in responding to student needs.

From the concept of reason put forward by aAl-farabi, this is a lecturer, students can use reason as a means of philosophical-logical thinking that will be guided to be able to work on and develop their natural thinking in accordance with Islamic values which will then develop (Nursa \& Suyadi, 2020). To foster individuals to be aware of God and Islamic values, they must be taught to be virtuous through active learning pedagogy (Tan \& Ibrahim, 2017). Scientific thoughts developed in Islamic universities will then produce power in modern life. These thoughts are able to create various systematic thoughts that synergize in building society and ultimately encourage the birth of critical thinking. This is why the mind is said to be the power of logic in building the treasures of Islamic scholarship (Gade, 2020). Education using philosophy means thinking critically, rationally, objectively, and normatively not based on a will on an emotional impulse (Husaini, 2020). Implementing Al-farabi's philosophy in higher education intends to orient a pattern of thinking that is critical, systematic, logical, and comprehensive-existentially integrative. The characteristic of thinking that is philosophically strong is the loyal flow of thought that becomes the basic capital in the self-development of young intellectuals. Of course, this is very much needed by students in building their competence as prospective thinkers, 


\section{Ahmad Asmuni}

scientists, professionals in their fields. In this case, Islamic universities need to formulate several important things, namely the essential nature of Islamic education, human nature, and the values and norms of Islamic education.

The second basis is about the purpose of education. Al Farabi views the purpose of education as a phenomenon in social life that must be given as early as possible in order to prepare individuals to gain luck in society. All educational activities must be directed to the transfer of knowledge and practical skills carried out in certain periods and cultures or traditions (Ahmad, 2020). Education must be able to guide individuals towards the perfection of life (written in Mabdi' 'Ara ahl-al-madinah al-Fadhilah) as a perfect human being (al-insan al-kamil) i.e. humans who have theoretical virtues, intellectual knowledge, and practical morals so that they can guide other human beings (Harahap \& Siregar, 2017; Al-Farabi, 1985). If it is related to education in Islamic tertiary institutions, the intended purpose is to generate ideas about policies and principles of Islamic education based on the creation of human beings by formulating Islamic practice methods and implementing a series of activities to achieve educational goals at Islamic Higher Education.

The benefit of the philosophy taught by Alfarabi focuses on the concept of value. According to Al-farabi, "the fostering and upholding of morality in society is part of education and is pursued through education. If education is not taken, moral values will disappear from society and life will be damaged. Education is needed by all levels of society because without education, humans will not achieve perfection and happiness in life" (Al-Farabi, 1985). With the right teaching method, the benefits of education can be felt. The trick is to broaden the horizons of thinking and become wiser in understanding educational problems. The implementation of this education encourages students to think reflectively using responsible intellectual freedom. Alfarabi also introduced the dialogue mode by emphasizing the importance of understanding or observing science by listening to what the educators said or known as the lecture method and the imitation/modeling method (Nursa \& Suyadi, 2020).

The literature explains that Islamic Philosophy which is implemented in higher education has four functions. First, the educative function is understood as an effort to educate with the aim of understanding the concept of ethical/adab morality values and gaining luck. Second, the function of developing thinking maturity through the process of transmitting knowledge carried out by educators to their students through the lecture method, the inhibition method (habituation) in teaching, the dialogue method, and the imitation/modeling method. Third, the function of strengthening belief in the truth by studying scientific knowledge in order to get happiness and become a perfect human being (insan kamil). Fourth, the function of worship as part of a servant to God (Kristiawan, 2016; Djamaluddin, 2014; Gholib, 2009). The literature states that studying the philosophy of Islamic education means entering the scope of a fundamental, very systematic, logical, and universal ideology about education (Gholib, 2009). Thus, it requires learning science that is relevant to educational activities in Islamic tertiary institutions, both regarding educational issues, educator problems, educational curriculum, and methods of the social environment. Thus, studying al-farabi's philosophy needs to understand the basic concepts 
of his thinking systematically, logically, and universally in accordance with the Koran and al-Hadith so as not to mislead.

It is undeniable that philosophy is capable of manifesting intellectual activities in laying the paradigmatic foundations for the Islamic scientific tradition in social life, including in supporting the development of science and technology. Islamic universities must be able to build Islamic philosophical scientific thoughts so that they can find the existence of thinkers, not just incompetent scientists. And also build a scientific culture that is moderate Islam and guide students to explore thoughts openly and accept criticism to sharpen their ideas and creativity. As the main function of higher education is to develop and disseminate knowledge through education and teaching activities to form competence academically or known as philosophical-logical. Higher education emphasizes aspects of education, research, and community service (Irianto, 2012; Bhakti, 2017). In essence, the philosophy of science in higher education has the aim of providing understanding, intellectual and cultural intelligence, and broad knowledge for humans. Therefore, Islamic universities try to raise awareness in students and society through a philosophy that knowledge and science are phenomena that must be studied and cannot be separated from human values.

\section{E. Conclusion}

This study has revealed that the Al-farabi philosophy is implemented in the practice of education at Islamic universities in Indonesia, as indicated by the scope, objectives, and benefits of education. First, the scope of education taught is about the concept of reason (intelligence). Second, the purpose of education is to prepare students through the transfer of knowledge and practical skills to obtain the perfection of life as human beings. Third, the benefits of the concept of value through moral development, teaching methods, and evaluation of learning at Islamic universities. The main conclusion obtained is that Alfarabi's philosophy in implementing education in higher education is very important for students and lecturers to improve self-competence. The government and Islamic universities need to pay special attention to educational practices in the realm of philosophy, especially from prominent Islamic figures who contribute to teaching systems of thinking logically, rationally, empirically, pragmatically, even with a wider scope. It should be understood that the philosophy of science is a method capable of redesigning civilization and creating positive-negative sides depending on its direction. So that previous research is recommended to examine more deeply the empirical relationship between philosophical studies and education at universities around the world.

\section{BIBLIOGRAPHY}

Abbas, M. B. (2021). Building a Modern Islamic College. In Whose Islam?: The Western University and Modern Islamic Thought in Indonesia (pp. 21-51). Stanford University Press. https://doi.org/https://doi.org/10.1515/9781503627949-005

Abdul Majid. (2017). Filsafat Al-Farabi Dalam Praktek Pendidikan Islam. Manarul Qur'an, 1- 
Ahmad Asmuni

13 .

Ahmad, G. (2020). Pemikiran Pendidikan Islam Menurut Al-Farabi. JIEBAR: Journal of Islamic Education: Basic and Applied Research, 1(1), 48-64. https://doi.org/10.33853/jiebar.v1i1.6o

Al-Farabi, A. N. (1985). Mabadi Ara Ahl Al-Madina Al Fadila. (Terj. R. Walzer, Ed.). Claendon Press.

Beach, J. (2012). College: What It Was, Is, and Should Be-Updated Edition. The Journal of College Student Retention. Princeton University Press. Retrieved from https://www.researchgate.net/profile/J_Beach/publication/255961822_Requiem_for_ the_College_Idea_Andrew_Delbanco\%27s_Beleaguered_Defense_of_Liberal_Arts_E ducation/links/00463520fa42ce5d25000000.pdf

Bhakti, D. D. (2017). Sistem Informasi pengelolaan arsip perguruan tinggi. Teknologi Pembelajaran, 2(September), 353-361. Retrieved from https://journal.institutpendidikan.ac.id/index.php/tekp/article/viewFile/124/441

Biesta, G. (2021). World-Centred Education: A View for the Present. Routledge, Taylor \& Francis Group.

Djamaluddin, A. (2014). Filsafat Pendidikan. Istiqra': Jurnal Pendidikan Dan Pemikiran Islam, $1(2), 135$.

Gade, S. (2020). Integrasi Keilmuan Sains \& Islam. Ar-Raniry Press.

Gholib, A. (2009). Filsafat Islam. Faza Media.

Guha, M. (2018). Encyclopedia of Educational Philosophy and Theory. Reference Reviews, 32(4), 12-14. https://doi.org/10.1108/rr-12-2017-0262

Halik, A. (2013). Dialektika filsafat pendidikan islam (argumentasi dan epistimologi). Istiqra, I(1), 22-28.

Harahap, M., \& Siregar, L. M. (2017). Konsep Pendidikan Islam Dalam Membentuk Manusia Paripurna. Jurnal Pendidikan Agama Islam Al-Thariqah, 2(2), 148-163. https://doi.org/10.25299/althariqah.2017.vol2(2).1040

Husaini, A. (2020). Filsafat Ilmu: Perspektif Barat \& Islam. Gema Insani.

Huzain, M. (2018). Pengaruh Peradaban Islam Terhadap Dunia Barat. Tasamuh: Jurnal Studi Islam, 10(2), 355-377. https://doi.org/10.32489/tasamuh.41

Ikhwan, A. (2016). Perguruan Tinggi Islam dan Integrasi Keilmuan Islam: Sebuah REalitas Menghadapi Tantangan Masa Depan. Jurnal At-Tajdid, 5(2), 159-187. Retrieved from http://ejournal.inismupacitan.ac.id/index.php/tajdid/article/view/18

Irianto, S. (2012). Otonomi perguruan tinggi: suatu keniscayaan. Yayasan Pustaka Obor Indonesia.

Jamal, N. (2017). Model-Model Integrasi Keilmuan Perguruan Tinggi Keagamaan Islam. KABILAH: Journal of Social Community, 2(1), 83-101. https://doi.org/10.35127/kbl.v2i1.3088

Karo, T. K. (2020). Perkembangan Epistemologi Dan Institusi Perguruan Tinggi Islam Indonesia. WARAQAT: Jurnal Ilmu-llmu Keislaman, 2(1), 29. https://doi.org/10.51590/waraqat.v2i1.49

Kindi, A. (1950). Risalah al-Kindi Fi al-Aql. Dar l-Fikr 'Arabi. 
Kristiawan, M. (2016). Filsafat Pendidikan. Valia Pustaka.

Maslaha, A., Suryani, \& dkk. (2018). Urgensi Iptek Dalam Pengembangan Pendidikan Islam. Jurnal Penelitian Pendidikan \& Pembelajaran, 5(2), 47-55.

Nazir, M. (1988). (1988). Metode Penelitian. Ghalia Indonesia.

Nursa, R. A., \& Suyadi. (2020). Konsep Akal Bertingkat Al-Farabi dalam TEori Neurosains dan Relevansinya dengan Pendidikan Islam. Tawazun: Jurnal Pendidikan Islam, 13(1), 1-17. https://doi.org/10.32832/tawazun.v13i1.2757

Parens, J. (2012). (2012). An Islamic philosophy of virtuous religions: introducing Alfarabi. SUNY Press.

Putra, P., \& Aslan. (2020). Pengembangan Bahan Ajar Berbasis Imtaq Dan Iptek Di Era Revolusi Industri 4.0 Pada Mata Pelajaran Sains Di Madrasah Ibtidaiyah. Ta'Limuna, 9(1), 143-147.

Rahim, R. (2018). Urgensi Pembinaan Pendidikan Agama Islam di Perguruan Tinggi Umum (PTU). Jurnal Andi Djemma, 1(1), 17-26.

Ramdhan, D. F., \& Siregar, H. S. (2019). Manajemen Mutu Perguruan Tinggi Keagamaan Islam Swasta (Ptkis). Jurnal Perspektif, 3(1), 75. https://doi.org/10.15575/jp.v3i1.40

Setiawan, A. R. (2020). Islamic Education in Southeast Asia. Islamic Education in Southeast Asia, 2(April), 1-10. https://doi.org/10.31237/osf.io/e794d

Simas, S. (2020). The Philosophy and Practices that are Revolutionizing Education and Science. Journal of Librarianship and Scholarly Communication (Vol. 8). https://doi.org/10.7710/2162-3309.2348

Singgih, M. L., \& Industri, J. T. (2008). Faktor-faktor yang mempengaruhi kualitas pendidikan pada perguruan tinggi. In Seminar Nasional Teknoin (pp. 133-141). Teknoin. Retrieved from https://journal.uii.ac.id/Teknoin/article/view/2108

Sonita, E., Miswardi, M., \& Nasfi, N. (2021). The Role Of Islamic Higher Education In Improving Sustainable Economic Development Through Islamic Entreneurial University. International Journal of Social and Management Studies, 2(2), 42-55.

Stosic, L., Dermendzhieva, S., Tomczyk, L., \& Dermendzhieva, S. (2020). World Journal on Educational Technology: Current Issues Information and communication technologies as a source of education. World Journal on Educational Technology: Current Issues, 12(2), 128-135.

Tan, C., \& Ibrahim, A. (2017). Humanism, Islamic Education, and Confucian Education. Religious Education, 112(4), 394-406. https://doi.org/10.1080/00344087.2016.1225247

Türk, N., Kalaycı, N., \& Yamak, H. (2018). New trends in higher education in the globalizing world: STEM in teacher education. Universal Journal of Educational Research, 6(6), 1286-1304. https://doi.org/10.13189/ujer.2018.060620

UniRank. (2021). Top Islamic Universities in the world 2021 uniRank University Ranking. UniRank, p. 8. Retrieved from https://www.4icu.org/Top-ReligiousUniversities/Islamic/

Widiawati, N. (2019). Reformulation Of The Islamic Education Philosophy: A Study of the Epistemological Thought of al-Farabi. Al-Afkar, Journal for Isalmic Studies, 2(1), 48-63. https://doi.org/10.5281/zenodo.3553815

Dinamika Ilmu, Volume 21(2), 2021 


\section{Ahmad Asmuni}

Woods, A., McNiff, J., \& Coleman, L. (2018). A Comparative Analysis: Assessing Student Engagement on African-American Male Student-Athletes at NCAA Divisional and NAIA Institutions. Education, 138(4), 356-368.

Ye, Y. (2019). On the Important Role of Marxist Philosophy in Contemporary College Students ' Education. In International Workshop on Education, Development and Social Sciences (IWEDSS 2019) On (pp. 1046-1050). Francis Academic Press 